\title{
SOME COMMENTS ON THE NATURE OF THE NATIONALIST REVIVAL IN FRANCE BEFORE I9I4
}

It is frequently asserted by students of the history of the Third French Republic that the years before I9I4, and especially from I9I I to I9I4, were a period of nationalist revival, ${ }^{1}$ a somewhat exceptional period when politics were dominated by a novel concern for national unity, prestige, and power; by calls for order, tradition, and discipline; and by catchwords connected with all these things. I propose to inquire first into the social aspect of this apparent change in the ruling ideology of the Republic, and then into the background and nature of the Nationalist movement.

To begin with, it might be well to touch very briefly upon the attitudes and sympathies of the different social classes, insofar as these can be apprehended. Any acquaintance with the life and literature of the time should convince us of the reality of class-consciousness and class-divisions, sometimes of a very meticulous kind. However, the main division in this case will have to be classic almost to roughness, and regard the aristocracy, the middle-classes, and the rest.

At the beginning of the twentieth century, the first of these had not lost all political and still retained a great deal of social influence, particularly in the countryside. Purged of its eighteenth-century scepticism, the nobility had moved through Royalism to Catholicism, the defence of the Church having proved a better proposition than the restoration of the Monarchy. The great bastion of their power lay in the West - especially in Anjou, Maine, and Vendée - where they still made elections in the twentieth century much as the Earl of

1 Cf. W. C. Buthman, The Rise of Integral Nationalism in France, New York 1939; E. M. Carrol, French Public Opinion and Foreign Affairs, 1870-1914, New York 193 I; D. W. Brogan, Development of Modern France, London I 947; A. Capus, Les Moeurs du Temps, Paris I912; A. Chéradame, La Crise française, Paris I9I2; V. Giraud, Le Miracle français, Paris 1914 ; and many others. 
Brentford made them for Phineas Finn at Loughton in the nineteenth. This aristocracy, whether legitimist or ralliee, was fundamentally antirepublican, patriotic by tradition, and not at all "nationalist" in any party sense. The constructive part of the Nationalist platform they had always advocated as a matter of course, unless they had taken it for granted to the extent of not thinking it worth the mention. The rest was probably a matter of indifference to them. They naturally showed some interest in the "integral nationalism" typical of the new mood, and of that vociferous representative of the new mood, the Action française. But where their power was absolute, as it was in the West, they had no need of it, and could afford to ignore it in political practice. It was in the South-West of France, where their influence was thin, that men like the Marquis de Lur-Saluces and Mgr. de Cabrières, good legitimists as they were, saw in the nationalism of the Action française a useful channel for their policies. ${ }^{1}$ In western towns, where the Action française did wield some influence, there was not alliance but competition and struggle, in which the Right divided, and the weaker party - in this case the Catholic middle-class - won against the stronger aristocratic faction by securing the support of the new Nationalists. ${ }^{2}$

This serves as a useful reminder of the influence of the Church, even where its power is not predominant. Such influence as the Church retained, had been exerted in the early nineties on behalf of the Republic to bring about, however half-heartedly, the ralliement by which an important section of the Catholic Right left the Royalist camp and accepted the established order. But the institutional traditions and the class connections of the leaders of the Church made it, and them, lean heavily towards the Right even before pacifist Radicals had provoked their enmity by their anticlericalism. Throughout the life of the Third Republic ecclesiastical influence appears openly, though not officially, on the side of Nationalism. It was the Catholic alliance in the more specifically Catholic parts of the country (Normandy, Brittany, Basque country, Catholic areas of the Cévennes and the Vosges) which gave the Nationalists heart. But, once again, Catholi-

1 They accepted the Nationalist alliance as they accepted any alliance with Right or Centre, e.g. as it suited them. Compare maps ${ }_{3} 3$ and is in F. Gogucl, Géographie des Elections françaises, Paris $195 \mathrm{r}$, and A. Siegfried, Tableau Politique de la France de l'Ouest, Paris 1913 , p. 4I7, to understand how lukewarm those Western regions where nobility was dominant were in supporting, say, the economic policies of the Right, whereas they reacted strongly on issues of national interest or prestige which affected their patriotic outlook.

1 In the Sables d'Olonne, for instance, the Action française allied with Catholic and bourgeois interests in I9I4 to secure the defeat of Henri Bazire, successor of Drumont as editor of La Libre Parole and leader of a rival movement on the Right. 
cism was the local reality, Nationalism only its occasional political expression - and not the only one. ${ }^{1}$ Whatever forms Church power might take, however ferocious the family quarrels in which it might indulge, it remained Catholic, and Nationalist if at all because it was Catholic.

This official Right of aristocracy and Church hardly alters its orientation in terms of political attitudes and language during the twentyfive or thirty years before 1914 . The twentieth century finds it on much the same positions which it held a decade before, and which it will hold a decade and more later. There is little or no question of change or development about it: the most we can say is that it awaits the swing of the pendulum which will restore its ideas to the favor of political fashion.

The second of our social classes, tremendously diversified, shading off into its rivals at both ends, should provide most of the material for a study of contemporary politics and political opinions, as it provides most of the personnel of the political, intellectual, and administrative worlds. We need not consider those few members of it, grands bourgeois like Casimir-Périer or Pouyier-Quartier, whom only the nobility know (as they know themselves) not to be of their own. Below them baute and moyeme bourgeoisie had in common a snobbery which made the sanction and frequentation of the aristocratic world one of their dearest aspirations. Vulgar academicians, ignorant of social niceties, may have considered the drawingroom of Mme. Verdurin (in M. Proust's A la recherche du temps perdu) to be the height of fashion. But Mme. Verdurin herself knew better, and did her best to shed her awkward Dreyfusist connections in order to pass like the camel of the parable through the eye of the Guermantes needle.

It was, however, less the social aspirations of the bourgeoisie than a new community of interest which made it move towards positions which the aristocracy had held for forty years. I 848 had done much to shake the Voltairianism of the bourgeoisie, and 1871 had confirmed this tendency. At first religion had been good for the people, then it had provided for the children's education, at last it had appeared as that essential element of moral and social discipline which seemed so signally lacking in modern democracy. It was also worth considering that, by going to church and to church functions, one could meet the local chattelain, and even perhaps penetrate into the little world of the 1 Thus we find the Catholics putting up "a free-thinking Republican" as they did at Rennes in 1914 to secure the defeat of a distrusted Catholic like Louis Deschamps, or indulging in intramural struggles like those which preceded the election of Paul Simon at Brest against another Catholic candidate. Cf. P. Delourme, Trente-cinq ans de politique religieuse, Paris $1936, \mathrm{Ch}$. VII, passim. 
nobility. Nobility and bourgeoisie met in defence of the Church, as some of them had met in defence of the General Staff, and common political interests sometimes opened doors upon which neither economic nor cultural considerations had prevailed before.

But, beyond political, material interests also drove the bourgeoisie from the ranks of the party of movement, as François Goguel has called it, into those of conservative defence. In the years after I87I, layer after layer of the middle class came to the conclusion that enough had been done to alter the face of France, and that further change should be opposed. The old bourgeois aristocracy (if the term be allowed) of the country towns had its day with Thiers and MacMahon, disapproved of Jules Ferry's anticlericalism, and went into opposition with Jules Simon in the eighties. Their fellows of the industrial and commercial world, survivors of what men still called the Gambettisme d'affaires, did not follow them for another decade, until the defeat of the moderate Méline and the critical years of the Affaire persuaded them of the primary importance of social defence with all its implications.

The middle and lower-middle class, the real Third Estate, took longer to come round. It harboured few of the social ambitions of the upper layers, and was easily persuaded into a "radical" policy as long as this radicalism stuck safely to democracy and anticlericalism. The appearance of working class demands was however enough to frighten them away - not from Radicalism which was by then no more than a harmless label, but from further reform. This class was not only antiSocialist but anti-state, and one of the reasons for such an attitude is expressed in Pauline Bergeret's words to her father:

"L'Etat, mon père, c'est un monsieur piteux et malgracieux assis derrière un guichet. Tu comprends qu'on n'a pas envie de se dépouiller pour lui." 1

Thus, though by 1905 it was the radicalism of this class which dominated government and Parliament, its mistrust of the state power toned down any program of social reform, and turned it quietly into a conservative force.

In its lower reaches, this layer merged with the working-class; and this lower-middle class of small shopkeepers, shop assistants and office workers, afraid of oppression from above and of losing their identity in the proletariat below, without exactly abandoning the hope of forward movement, offered by its vulnerable and incoherent nature just those opportunities, just that temper of mind, on which all the Boulangisms and all the demagogues could try their hand. A pro-

1 A. France, Histoire Contemporaine, Paris 1948, p. 712. 
gram like that on which Anatole France shows us the Nationalist Lacrisse riding to victory in the ward of the Grandes-Ecuries, could appeal to all these groups:

"Défendre l'armée nationale contre une bande de forcenés. Combattre le cosmopolitisme. Soutenir les droits des pères de famille violés par le projet du gouvernement sur le stage universitaire. Conjurer le péril collectiviste. Relier par un tramway le quartier des Grandes-Ecuries à l'Exposition. Améliorer le service des eaux." 1

It seems fairly clear that, by the early years of our century, the middleclass, whether notables like the Siegfrieds of Le Hâvre, or on the confines of the working-class like the market-gardeners of Bobigny on the outskirts of Paris, ${ }^{2}$ had left the reformist Republican camp - had left "the party of movement". They were either concerned to obstruct changes which they feared would endanger the established order, or prepared to attack the established order to secure vague but violent changes. The paradoxical result was that both these tendencies brought grist to the Nationalist mill: the conservative because it found in Nationalist energy a not unattractive reassurance, the cataclysmic because it was tempted by their equivocal programs and by the passion of their demagogy.

One section of the middle-class cannot well be included under any of these categories, and that is the great and growing body of State employees who were beginning to develop not only a strong feeling of common interest, but also a concrete syndical structure - in the civil service, the teaching professions, etc. Though as a class their traditions were strictly bourgeois, perhaps due to the centralization of their services, the low level of pay, the size of the organizations of which they were a part, the analogy of their working conditions to those in great industrial enterprises, their sympathies went to the parties of movement and social reform, sometimes indeed of violent reform.

When speaking of "the rest", one nods in passing to a great indifferent mass of town and especially country-dwellers, whose parsimony as a rule outweighed patriotism and social spirit, and who swayed with the wind of the active, vocal minority, and of local tradition. We cannot, however, ignore the influence of the increasinglyorganized workers' parties, largely united by the S.F.I.O. in the political field, though the Independent Socialists (more independent,

1. Ibid., p. 743 ; the similarity to the Poujadist appeal might well be noted.

2 A. Siegfried, Mes Souvenirs de la 3e République, Paris 1946, passim; M. Agulhon in P. George, etc., Etudes sur la Banlieue de Paris, Paris I950. 
most of them, than Socialist) were also important. Though any Syndicalist would claim that parliamentary Socialists did not represent the working-class, they interested it enough to secure ever greater electoral support in the years before the war, and to frighten all the defenders of property and of the established order with the prospect of an impending Götterdämmerung.

Different as these varied groups and interests were, they had one thing in common - a basic or growing distrust of the system of government which some of them condemned for being too harsh and others for being too weak, which Royalists and Socialists condemned on principle, and others because it seemed unable to secure for them be it the stability, be it the opportunities, which they desired. Men who were in temporary possession of the levers of power may have believed that the system could work well enough, and there were those who-like Barrès or Jaurès - thought that any radical change would probably be for the worse. Nevertheless, whether change appeared as a threat or as a promise, it was bound to affect a growing section of the politically significant minority, the men who made opinions and sometimes policies.

Such men would count among their number leaders and militants of political parties; writers and journalists; bodies representing or creating certain vested interests such as the unions, the Institut, or the Université; and also individuals whose opinions were invested with significance by the position they occupied in government or society. These leaders of opinion considered themselves, and were treated as, a social and intellectual élite, an élite which owed much of its cohesion to family relationships or student friendships. Cousins and in-laws spread the old-boy network from party to party, from salon to salon; and where no cousinage existed, a student camaraderie that amounted almost to free-masonry might make up for it. Thus, nearly $95 \%$ of the men appointed to the diplomatic and consular services between 1907 and 1927 were drawn from the graduates of the Institut des Sciences Politiques. Here we have a small group of able and influential people who, for the greater part, shared a vested interest in the established order and who eventually came to look upon Raymond Poincaré as their standard bearer, and to agree upon standards which (even when they were called Poincarist) were in effect Nationalist. ${ }^{1}$ The thing worth noting is that these slogans of national unity, discipline, confidence and power were not new, not original, did not have to be invented.

1 Poincarism was the respectable Nationalism of 191 2-19I4, which "allowed all good men to come to the aid of their party" by providing a leader acceptable to good Republicans. 
The Nationalist idea of the superiority and strength of France, an idea to which one could appeal in order to perfect national unity and selfconsciousness, an idea which could be exploited for politically significant ends, was already a tradition to be remembered or revived. After 1871, Nationalism in France had been associated with the Left; chauvinism had been the preserve of the uncultured, of the masses. The Jacobin tradition of the Left was not dead. When the twentieth century opened, everyone still remembered its latest eruption in the Commune, and in the efforts and peregrinations of Gambetta.

Gambetta had been considered dangerous for fear that his revanchard intransigence would endanger the peace of France. But Gambetta's thought evolved as did his position, and increased power brought with it increased inclination to compromise. His political heirs, first Ferry, then Méline, sought for peace without forgetting that much of their moderate Republican support lay in the patriotic and vengeful Eastern departments. Since the danger of war lay on the Rhine, they concentrated their efforts on reconciling colonial and financial expansion with a policy of détente towards Germany. This gave their supporters the satisfaction of French successes without the dangers of a German war. Ferry and Méline were moderate men, and a positive policy along such theoretical lines as the Nationalists advanced at the time could not be expected from them. This left the Nationalist and revanchard arguments, convenient weapons, in the hands of the opposition. Nationalism remained a Radical preserve for many years: Boulanger, for one, rose first to power, then to notoriety, with Radical support. Many of his followers were jacobin and revanchard, lower and lower-middle class men of little or no property. His chief enemy was Jules Ferry. Boulangism is typical of such Nationalist movements as had to rely on a single leader, on the enthusiasms and prejudices of individuals rather than of groups, and on uneasy deals and alliances that might keep them going.

When faced with the opposition of established parties Boulanger collapsed, and his fragile structure collapsed with him. It was not Boulangism that survived, but ideas which had existed before it, and on which it had relied for its success. If Boulangism lived on, it was not through some strange virtue of its teaching, but because it was itself the transient, if convenient, expression of a tendency which took different forms and labels, sought different support, but remained fundamentally constant in character and aim. $\Lambda$ nd it is worth noting that it was in the regions most inclined towards that tendency-in the North, in the East, and in Paris - that Boulangism reaped some of its most interesting successes with the General's triumphant elections in the North and in Paris, the electoral victory of young Barrès at 
Nancy, and the eventual defeat of Jules Ferry in his own Vosges constituency.

This spirit lived on. The Panama scandal of 1892 was the Boulangists' tit-for-tat with their victors of 1889 . It has been said that the Dreyfus affair was the last effort of the Boulangist spirit. This attributes too much importance to one manifestation of a tendency that was much longer lived. We learn better if we look to L'Appel au Soldat, in which Barrès makes his young hero, Sturel, vow after the General's fall: „Nous retrouverons des autres boulangismes!" Sturel would not have been too old to take an active part in the nationalistic activities of I9II-I4, and many of Sturel's old companions did. His creator, Maurice Barrès, carried his ideas through the years, giving them first coherence, then a name. The name came when, in 1892 , he first used the word "nationalism" in an article concerning the then-current debate between partisans of the classical French tradition, and "romantic" admirers of Tolstoy, Ibsen, and Maeterlinck. The transition from literary nationalism to political nationalism did not take too long.

The Dreyfus affair offered the doctrine an opportunity both to spread and to affirm itself. It was then, in 1899 , that Barrès defined his idea of a nationalist:

"He is a man who relates everything to France, who judges everything, even the abstract truth, in terms of French interests. The assertion that a thing is good or true begs the question 'In relation to what is this thing good or true?' Otherwise one might as well say nothing." 1

The Nationalism of Barrès was republican, traditionalistic, respectful of the established order even when he disapproved of it. Out of the Dreyfus affair, however, inspired by Barrès but differing from him on many points, grew another Nationalism. A rebellious Nationalism, anti-republican, whose assertive traditionalism rejected a whole century of French tradition, revolutionary because Royalist, and chauvinistic by reaction against the foreign elements that it felt were swamping French life and culture. ${ }^{2}$ In the mood that prevailed in the pre-war years the activities of these Nationalists had their clear share;

1 La Terre et les Morts, Paris 1899 , p. I 2.

${ }^{2}$ Cf. Maurras, Action française, March 3, 1920. One may wonder whether these extreme characteristics were not due, at least in part, to the loss of electoral influence, and to the series of disastrous defeats inflicted upon the Right in general, and upon Nationalist candidates in particular, at all elections after 1898 . 
their preaching heightened the defensive tone of France, and also the aggrievedly offensive tone of Germany. Effect and cause were so clearly interconnected that they are even now inseparable. Paris too must be granted its proper importance, for there the movement was in great measure concentrated. Nor was this surprising or new: the city had been revolutionary when the government was conservative, radical when the government was moderate; Boulanger had flourished to its cheers in 1889 , anti-Dreyfusard nationalism ten years later. It would always be radical in its own fashion: before 1914 it was destined to see the greater part of the new nationalistic ferment. Again, this is understandable from a class point of view: at a time when France seemed threatened by the foreign enemy, the Nationalists stood most explicitly for French greatness and the power to affirm it; at a time when the social order seemed threatened, the Nationalists spoke up loudly if not clearly against those who attacked it. "The best people" would not condone their vulgar and violent methods, but they would look upon them with discreet sympathy. The solid bourgeoisie would find little good to say for their hooliganism, though its student sons would join the Camélots du Roi or chant Nationalist slogans. However, those lower middle classes uneasily teetering between bourgeois respectability and the disgrace of proletarianization - small shopkeepers, shop assistants, clerks, butchers (there should be a chronicle of the part played by butchers in the annals of Nationalist leagues!), and so on - could and would be more decisive about it, and the vote was not their only means of expression.

Here was a numerous public, relatively stagnant, relatively backward, opposed to changes which might threaten the established order and its own precarious social position, yet impatient of the established order which appeared weak, indecisive, inefficient, hardly a trustworthy champion of internal order or national prestige. "Respectable men" revolt against the corruption that would be the country's ruin and that could so easily be attributed to foreigners and foreign ideas. "Little men" revolt too, against the growing oppressiveness of state and money power, and become antisemitic "because the Jews have all the money". It is all rather complex, hardly ever clear, but clearly good material for Nationalist agitation which offered a ground upon which persons moved by vague and contradictory aims and dissatisfactions could meet with profit. But, though numerous, such people do not contribute much to national opinion. "The best people" do. And the most influential of these were in Paris.

We know, of course, that in terms of political and cultural activity, Paris has long been the centre of France. If Saint-Phlin leaves it for 
his native Lorraine and a life of political insignificance, his fellowdéracinés remain, as did his creator Barrès; as does also Jules Romains' country-born Jerphanion who may talk of his native soil, but who makes his life in Paris and remembers his childhood home chiefly for electoral purposes. M. Bergeret, unhappy and ineffective in the provinces, comes into his own when he is transferred to Paris; and the correspondence of Charles Péguy shows to what extent banishment from the metropolis troubled men who were, or wanted to be, active in political and cultural life. ${ }^{1}$ As Versailles under the Monarchy, so Paris under the Republic was the place where things could be done, where men could get on, la foire sur la place where centered the strings of a myriad social, economic, and cultural activities. And so, however much he might talk of Lorraine, it was in Paris that Barrès produced himself; and the spell of the sorceress Martha was not strong enough to keep other félibres beside Maurras in their native Provence. They were right, for in the countryside things had changed little since Renan recorded his impressions of the electoral campaign of 1869 in Seine-et-Marne. As for the myriad little towns, communes whose activity has been so well described in Roger Thabault's excellent study of his own Mazières-en-Gâtine, their fate, like that of M. de Gromance, was settled in Paris. Their political ideas hardly less so. ${ }^{2}$

It would be a mistake, certainly, to think of French public opinion in the pre-war years as one, coherent, united sentiment, gradually rising against the ever more clearly perceived and ever more resented threats from abroad, from within, or both; even though broadly and superficially this is the very picture of events. Obviously, public opinion is never wholly united, never wholly coherent, and seldom rises to a pitch of passion without being influenced - that is, without the use of propaganda. Such propaganda came wholly from Paris, through the conversation held there, the newspapers published there, the appointments made there, and the public speakers who went out from there (even if they were not by any means all Parisians themselves) all carrying a point of view forged and current in Paris. The two or three village notables, and anybody else who read or listened, were the local counterpart of the minorite agissante at work in Paris. But the provincial editors also read the Paris papers, maintained a Paris office if they could afford it, subscribed to a Paris news-agency otherwise, and the Paris Letter was a staple feature of the local newspaper. The most widely read provincial newspaper, La Croix, was itself little

1 Cf. Barrès, Roman de l'Energie Nationale; Romains, Hommes de Bonne Volonté; France, op. cit.; Bulletin de l'Amitié Charles Péguy, passim.

${ }^{2}$ Cf. Renan, Reforme Intellectuelle et Morale, Oeuvres, Paris 1947, I, p. 347; Thabault, Mon Village, Paris I 944 ; France, op. cit. 
more than a copy of the Parisian editio princeps, and even great provincial dailies like the Dépêche de Toulouse or the Progrès de Lyon read like brothers or echoes of the Paris press.

All this was important. And it would be difficult, also, to overestimate the significance and the influence of contemporary literary production - especially at its most accessible, most popular level, that of the novel and the play. A great deal of attention has been devoted to French writers' reactions to the crisis of the times, but students have focused with determination on evidence furnished by what are largely selfconscious documents, whether contemporary or ex post facto: diaries, correspondence, essays and articles, memoirs published later, and so forth. Yet the literary forms most likely to affect and reflect general public opinion - particularly popular novels - have been rather neglected. ${ }^{1}$ True, the evidence is clearer, less ambiguous, more accessible too, in the important contemporary investigations of opinion in literary and student circles; ${ }^{2}$ in the critical essays of men like Brunetière, Lemaitre, Capus and Faguet; in the mass of politicoliterary writings by Massis and Sorel and Maurras and Daudet and Bainville and Barrès; above all, perhaps, in the brilliant work of Charles Péguy, full of reflections of (and on) the contemporary scene. And yet there is a good deal left of evidence and propaganda: even if we only mention the plays of Hervieu and Brieux, Emile Fabre and Jules Lavedan and Paul Bourget. Even if we remember only the novels of Barrès and of Ernest Psichari, of Romain Rolland and Paul Bourget, and the solitary but important work of Roger-Martin du Gard, which presents itself as an essential document for the student of the new atmosphere. Written in 1912, published in 1913, the changes of the time are emphasized in it because they appear emphatic to the author. And it was natural that Barois, the idealistic writer-politician formed in the Dreyfus period, should be struck by the change of temper among the young. Open Jean Barois anywhere and you will find a running chronicle of contemporary intellectual attitudes: open it at the chapter where Barois grown old interviews the young representatives of the new Nationalist and Catholic middle class, and you will find the stuff of the times. The emphasis falls heavily on the catchwords

1 CF. some instances of this attitude in P. Hazard, L'Ame française à la veille de la guerre, in: Revue internationale de l'enseignement, LXXIV, r920; E. R. Curtius, Die literarischen Wegbeteiter des neuen Frankreichs, Potsdam 1920; J. C. Cairns, Letters and International Politics, I9II-1914, in: University of Toronto Quarterly, XXIII, 1954; R. S. Bourne, Maurice Barrès and the Youth of France, in: Atlantic Monthly, CXIV, I9I4. 2 Agathon, Les Jeunes Gens d'Aujourd'hui, Paris I913; G. Riou, Aux Ecoutes de la France Qui Vient, Paris 1913; E. Henriot, A Quoi Rêvent les Jeunes Gens, Paris 1913, are the most important. 
of the period: "Discipline, Heroism, Renaissance, Génie National"... "La France nouvelle, la France de la menace allemande, la France d'Agadir." Order must replace anarchy. Positive knowledge must replace vague philosophizing. The reader is told that one of the young men is in Normale-Sciences, not Normale-Lettres and that the other studies Law and Political Science: more "positive", useful, subjects that the Philosophy which Barois' generation would have chosen. They are stern, firm, and positive, without the weaknesses of dreams, or humour, or self-doubt. Even their regard for tradition and religion, which they see almost as one, is of a positive sort: traditional (that is Catholic) morality must be restored because of its disciplinary virtues.

This last point is borne out by the evidence of Henri Massis who has presented the Catholic revival of the time as part of a trend towards authority, hierarchy and discipline, rather than of a search for ultimate truth. It agrees with the testimony of M. Petit who speaks of Claudel as being "au premier rang des poètes qui voient dans le catholicisme la grande école d'énergie". It fits in with the ideas of Ernest Psichari. ${ }^{1}$ The whole discussion in Barois is paralleled in Agathon's Les Jeunes Gens d'Aujourd'hui, and in Emile Henriot's A Quoi Rèvent les Jeunes Gens (Enquête sur la Jeunesse Littéraire), both published in I9I 3 - the same year as du Gard's novel. Henriot's Enquête quotes a lot of young writers (G. Duhamel, J. Copeau, J. Boulanger, A. de Tarde, H. Clouard) much to the same effect as the interlocutors of Jean Barois. And Julien Benda, when he later writes Un Régulier dans le Siècle, confirms that "tout un monde littéraire ne voulait plus savoir que l'âme 'française', les vérités 'françaises'..." 2

In Aux Ecoutes de la France Qui Vient, also published in I9.13, a Protestant youth leader, Gaston Riou, delcares: "Two men above all represent Young France - Charles Péguy and Romain Rolland." 3 Péguy in those days was not widely-read, though Romain Rolland himself has very appositely written of him and of these times that "toute une jeune génération française marchait au devant [de la guerre], joyeusement, et qu'en tête marquait le pas Péguy, entonnant la Marseillaise du Marathon." "But in "Jean Cristophe" Rolland himself, having written a novel in which a whole generation discovered its own reflection, cannot but describe the new mood and the effects of the new Nationalism - the new Catholic revival which affects Aurora

1 Cf. H. Massis, L'Honneur de Servir, Paris I937, p. I7; M. Petit, Histoire de la France Contemporaine, Paris 1916, p. 460; Weber, Psichari and God, in: Yale French Studies, No. 12, 1954.

2 Pp. 136-37.

3 P. 283.

- Péguy, Paris 1948, I, p. 246. 
and Georges; the reaction, against Free Thought, towards war and chauvinism that hurts Emmanuel grown old; and Jean himself cannot excape the impression that Europe "offrait l'aspect d'une grande veillée d'armes". Colonel House, one cannot help feeling, was somewhat less perspicacious.

With Ernest Psichari we come to an ideal type of quite another sort; a patriot of good family, a grandson of Ernest Renan, a nationalist, an admirer of Maurras, a soldier by choice, a Catholic by conversion, the very image of the perfect youth of the Nationalist Revival. His evolution can be traced through his two novels: L'Appel des Armes, exalting the order, discipline and patriotic virtues of military service, and Le Voyage du Centurion, exalting the superior order, discipline and spiritual virtues of Christian service. In connection with Psichari, we might also notice Paul Acker whose novels are clearly vehicles for the discussion of militarism and anti-militarism, and of the new patriotic attitude that alone can save France from her present decadence. ${ }^{1}$

With Acker, however, we touch the demarcation line between the writers who depict and those who propagand; and the most influential of these latter at this time was without any doubt Paul Bourget with his "campagne de restauration nationale". ${ }^{2}$ Anti-democratic attitudes played an important part in the Nationalist Revival, and so did the need felt by some to preserve or restore the social and moral order threatened or affected by the "prevalent anarchy". The work of Bourget affords an excellent illustration of these themes. The divisions and discords of the Dreyfus affair had inspired him to try his healing pen on the nation's wounds. The inspiration of his social and political concepts comes, like that of Maurras, from Comte, Bonald, Le Play and Taine; and his porteparole characters, like Victor Ferrand in L'Etape (1902) are eager to cite their authority. Un Divorce (1905), L'Emigré (1907), continue to preach the virtues of "Travail, Famille, Patrie", social order and traditional values. The point is carried to a vaster public in the plays whose series begins in 1908 (some of them being novels adapted for the stage): Un Divorce, L'Emigré, La Barricade, Un Cas de Conscience, Le Tribun. The influence of the plays was the wider for being published also in the theatrical supplement of L'Illustration which would carry them automatically to the marble table-tops of many thousands right-thinking families. The influence of the literary figure was enhanced by that of the political columnist, co-author of the Billet de Junius in L'Echo de Paris. And

${ }^{1}$ Cf. Le Soldat Bernard, Paris I 910 ; La Classe, Paris n.d.

${ }^{2}$ Cf. A. Feuillerat, Paul Bourget, Paris 1937, P. 245. 
there are other - Barrès, Bordeaux, Bazin, revanchard, patriotic, traditionalistic, professeturs d'énergie. Léon Daudet, better in his chronicles than in his novels; Charles Maurras - a poet, an essayist, a pamphleteer, but as a novelist only a novelist manqué. But Anatole France, whose Histoire Contemporaine so brilliantly reflected an earlier period (as did the Roman de l'Energie Nationale of Barrès), gives us nothing or only a few flashes for this later time in La Révolte des Anges, and nothing at all to compare with the adventures of $\mathrm{M}$. Bergeret.

And if all these throw relatively little light on the activities of the Nationalist movement itself, they throw a great deal on the Nationalist mood, on the revival of patriotism, of national self-confidence and self-consciousness; on the new insistence on order, discipline, moral values, and the positive virtues; on the fashionable reaction against Free Thought, Socialism, empty values like Justice and Truth ${ }^{1}$, internal divisions (those created by anybody else), and generally the pernicious anarchy that had been born in 1789 and that had triumphed in 1902. Words against words perhaps. But Carl Becker has taught us how to identify the climate of opinion of a time by the words it favors most. By this token, the weight of literary evidence for the years before 19 I4 confirms the contemporary impression of a national and patriotic revival.

It might fairly be asked how far Paris reflected France or, better still, how far it reflected on France. True in the I8 50 's Paris "glimmered before Emma's eyes in an atmosphere of vermillion". But, just because Mme. Bovary over-indulged her literary tastes, may we assume that then, or half a century later, the provinces were devouring the products of the Paris presses? We probably may; there is evidence to show that the novels of Barrès and Bourget were popular, Jules Renard finds cultivated men in the Nièvre who know more than he of what goes on in Paris, and certainly the correspondence between Alain-Fournier and Jacques Rivière shows that there were then, as ever, circles in Bordeaux quite up to date on Parisian activities. Here is more proof of the focal importance of Paris, to which the Rastignacs and the Julien Sorels, the Pécuchets and the Sturels of the twentieth century still looked for inspiration, for opportunity, and (though often under protest) for leadership.

No doubt parliamentarians still glanced toward their wards with moderate apprehension, and ran their constituents' errands in Paris ministries. But the movement for parliamentary emancipation was already under way, and Proportional Representation, designed to free the deputy from too close dependence on his electors and place him 7 Cf. Jean Barois, L'Age Critique, I. 
under even closer dependence to party headquarters in Paris, was itself significantly enough part of the platform on which a "Nationalist" coalition fought and won the elections of 1919. Paris was winning.

So the new tendency towards patriotic emphasis is no less significant for being largely concentrated in a few regions which had long entertained it anyway, and in certain very active and articulate Parisian circles. Localized as it seems to have been, it is important enough to affect the parliamentary behavior of sound anti-clerical politicians like Thomson and Messimy, the public behavior of grand old representatives of the Republican camp like Ernest Lavisse and Anatole France, the orientation of one-time Dreyfusist strongholds like the Ecole Normale. ${ }^{1}$ It is obvious enough to be noticed by all interested observers, both foreign and French. ${ }^{2}$ And it is apparently strong enough to keep in power a President and a government who, if they did not actually seek war, yet accepted it as a part of their plans for France and for the future. But it is new only in a very limited sense; it is really a revival of attitudes never altogether abandoned, an emphasis on terms which fashion had slurred over for a while. What novelty there is in it lies in Paris. And that never was any novelty in France.

So we are justified in speaking of a Nationalist revival in the sense of that term; the problem remains that of defining the nature and the source of a movement which was undoubtedly there. ${ }^{3}$ And this problem arises, as must already be clear, from the confusion caused by different groups and individuals apparently moving together towards a common "nationalist" goal. The movement appears most clearly in dramatic events such as the election of Raymond Poincaré to the Presidency in January of 1913 , or the passing of the law prolonging military service from two to three years in the summer of the same year. But it manifested itself over a much longer period

1 Cf. Lavisse's yearly prize-giving speeches at Nouvion-en-Thièrache, reported in Le Temps; A. France, Discours de Réception for Marcel Prévost, April 2 I, 1910; H. Bourgin, De Jaurès à Léon Blum, Paris 1938 , passim.

2 E. Foumière, Dépêche de Toulouse, Feb. 10, 1913; H. Nicolson, Lord Carnock, London 1930, pp. 397-98; Die Grosse Politik der Europäischen Kabinette, Berlin 1922-27, IXL, p. 190, note 2; Amtliche Aktenstücke zur Geschichte der europäischen Politik, Berlin 1925, IV, p. 148; British Documents on the Origin of the 1914 War, London, $1926-$ 38, X, 2, p. 674; Un Livre Noir, Paris 1922-34, II, p. 304.

${ }^{3}$ R. Heberle, Social Movements, New York I95 I, Introduction, passim, tells us what a vague thing a "movement" might be, sometimes a mere trend or tendency, sometimes a factor in producing a trend, sometimes a response to a trend, sometimes a political party, sometimes something much less formal than that. Though to speak of a Nationalist party in connection with this period would give the wrong impression, it is correct to speak of a Nationalist movement because it qualifies under Professor Heberle's definition as "integrated by a set of constitutive ideas or an ideology". 
of time in fostering the mood that became first apparent and then apparently dominant as the Nationalist revival. Its make-up was not always clearly understood; many good Republicans merely recognized behind it their traditional antagonists - Clericals, Monarchists, and Nationalists: "Boulangism in 1889 , Nationalism in 1899 , Nationalism again in 1908", wrote Le Progrès de Lyon on January 3, 1909, "but integral nationalism - that is to say monarchism. The Republic is undergoing its decennial crisis." And the very next day, Louis Vaugeois, elaborated the same idea in the Action française:

"Ainsi ces puissances de sentiment que Barrès en 1900 nous montrait, et avec raison, inertes dans les foules patriotes, ̀̀ l'idée de la Monarchie, les voilà, très incontestablement, qui se sont ébranlées depuis quelques mois dans les mêmes foules patriotes. Car il n'y a pas à le contester de bonne foi : c'était bien les mêmes gens à la salle Wagram, autour de Réal del Sarte, ces jours-ci, qu'en I 906-I 907 autour de Mercier ou Rochefort: or, quand la moindre allusion à Dreyfus et aux juifs mettait toute l'assistance debout, cannes et poings levés, c'était l'émotion "nationaliste" sans plus: celle même de $1899 . "$

He might have added "et de i 889 ".

It was easy to confuse the Nationalist movement with its noisiest and most active representatives who, to all but those forces themselves, seemed one with the traditional enemies of the Republic. But, in fact, it was much more than that: as Georges Sorel very sensibly told one of his friends, "On n'avertit pas les peuples avec des revues qui tirent à cinq cents éxemplaires." 1 The vocal Nationalists were not powerful, and hardly significant, politically or socially: where they could muster four or five thousands demonstrators for an occasion, the Socialists would gather I 50,000 when they really tried. ${ }^{2}$ And the good people of whom the Princess Radziwill writes in May of 1909 that they bunched together portraits of the Pope, tricolor flags, and effigies of Joan of $\mathrm{Arc}^{3}$ can be cited in connection with the newly-prevalent nationalist mood, but hardly in connection with the integral nationalism of the Action française.

We should understand the situation better if we consider the idea of Henri Bazire who, writing at the end of $191 \mathrm{I}$, pointed to the birth of a "New Nationalism". He attributed it to external causes and in

1 J. Variot, Propos de Georges Sorel, Paris 1935.

2 Cf. Le Progrès de Lyon, March 19, 1913; L'Humanité, May 26, 1913.

3 Lettres de la Princesse Radziwill, Bologna 1934, IV, 77. 
particular, to the general impression that Germany would never allow the country to live in peace:

"Before the revelation of the foreign danger, a new nationalism is born.... It does not stem from transports of enthusiasm, nor from a political movement, but essentially from an awakening of patriotism, and of reasonable patriotism at that..." 1

Nationalism and patriotism were used as equivalent terms, for that was how they appeared to him:

"On nous dira, votre nouveau nationalisme se confond tellement avec le patriotisme qu'il se dilue en lui, c'est une moyenne de l'èsprit public qui pénétrera plus ou moins les partis, mais d'où ne sort ni un programme positif, ni une méthode d'action suffisamment précise.... Vous allez encore nous parler d'ambiance. - Pourquoi pas?"

His article was the first attempt to analyze the new atmosphere. It called forth confirmation and warm agreement from readers and friends. And the spate of investigation which flowered during the spring of I 9 I 2 led Bazire to reiterate his opinion: the new nationalism was different from the old; it overflowed the limits of the old parties, and looked beyond the anxieties of internal politics. ${ }^{2}$

But this was going a little too far: it is undoubtedly true that the new nationalism was different from the old one. The same cries and the same canes might rise in the salle Wagram, but the mood that impressed foreign observers was to be found elsewhere too - in the press, in the schools, in the tone of the theatre and the publishing trade, in the Elysée beginning in 1913 , and the Army, and the Palais Bourbon. ${ }^{3}$ It was therefore more than just the bright flare-up of nationalist embers.

Now Mr. F. Hertz has explained in his study of "Nationalism in History and Politics", that certain contemporary triumphs of extreme nationalism "were facilitated by the attitude of many statesmen and politicians who were not in sympathy with their aims, but either believed that it was too dangerous for their own position and that of their partners to take energetic measures against them, or even considered them as necessary evils". And this illuminates the tolerance,

1 La Libre Parole, Dec. I3, I9I I May 8, I9I 2.

2 La Libre Parole, Dec. 6, 1911.

${ }^{3}$ G. Rozet, L'Eclair, September 1 s, I9 I ; P. Mulle, Dépêche de Toulouse, February 2, I91 2 ; J. Bardouz, L'Opinion, December 28, 191 2; L. Cury, L'Echo de Paris, January 2, I913; A. Brisson, Le Temps, February 24, I913; V. Marguerite, Le gôut de l'énergie, Paris I912; etc. 
the sympathy, the support which old-style Nationalists received from the new, it indicates the real forces behind the Nationalist revival, and it helps to clarify the confusion between its various components. "The typical nationalist attitude", writes Mr. Hertz, “... is to assume that national power and prestige are the best keys to all the treasures of the world, and that a strong State alone can solve the social problems and secure the best possible conditions for the development of national civilizations..." 1 This helps to point out why conservative and nationalist programs cannot really be one: the conservatives aiming at the conservation of states, liberties, privileges, situations; the nationalists aiming rather at the creation of new ones, "with prestige and power as the supreme goals". But it also shows why the superficial observer at a time when moderates and nationalists emphasized the importance of strong government and national prestige, could not see much difference between their respective programs. Why, in fact, patriotic conservative Poincarisme should look very much like patriotic extremist Nationalisme - to all but a few who, like Poincaré or Maurras, were in a position to know better.

The apparent unity, then, of the Nationalist movement and of the nationalist mood in the years before $\mathrm{I}_{9} \mathrm{I}_{4}$ is partly due to a confusion of catchwords, a concatenation of common slogans emphasizing patriotism, order, tradition, and discipline, a general tone whose coherence is more apparent than real. If we look closely we may distinguish an alliance of different tendencies, survivals, interests and tactics; and the sometimes-only-tacit collaboration of different men and groups leading to striking results, joining in striking policies, agreeing on striking measures, emphasizing first a latent then an elated patriotism. But the patriotic tone which characterizes the period after Igos was not new; it was, as we have seen, the same old thing monté en épingle. Neither Barrès nor Bourget waited until the pre-war years to adopt it; Péguy was a rabid patriot even when leading the Dreyfusist bands of the Ecole Normale down the hill of SainteGeneviève; Brunetière's ardent nationalism never wavered; when Jules Lemaitre joined the Action franfaise in 1908 it was no new departure for the ex-pillar of the Patrie française. People like these did not need clowns like Jean Richepin to show them the way. The way had already been traced, and the men who followed it in 1914 had themselves laid some of its milestones in 1889 and 1899 .

Thus, to many of the people they affected, old Monarchists, steadfast Catholics, unreconciled Boulangists, unrepentant anti-Dreyfusards, the slogans of the new Nationalism had long been familiar. Others had

1 London I944, P. 35 and passim. 
been shifting gradually to an appreciation of their use. Some were moved, as Bazire has told us, by the revelation of foreign danger. And some, perhaps among the most politically-significant, merely saw them as handy slogans in a difficult political situation in which internal and external pressures were complicated by the demagogic demands of the current political system.

A movement, then, the nationalist revival? Only in the sense Professor Heberle tells us that we may sometimes use it, of "trend" or "tendency". A public opinion? Certainly as he defines it - "The prevailing publicly-expressed opinion on a matter of public concern, which can claim effective validity in a society." 1 Effective? We can have little doubt of it when we survey the French political scene before I914. But vague, incoherent, tangible but indefinable - and almost impossible to explain outside the detailed story of events. In that case, "vous allez encore nous parler d'ambiance?" After all, "pourquoi pas?" 